\title{
Juridical Analysis QR Code Inclusion in Deed Seen From Act No. 2 of 2014 on the Amendment of Act No. 30 of 2004 about Notary
}

\begin{abstract}
Angga Hardityo ${ }^{1}$, Amin Purnawan² and Setyawati ${ }^{3}$
Abstract. A public official authorized to make an authentic deed regarding all actions, agreements and statutes that required by regulation or desired by the public interest that is expressed in an authentic deed is a Notary. The competent authorities have the duty and obligation to provide legal certainty on a whim deeds poured in the form of Deed. The times and the modern era such as the present need for security in the Deed to prevent counterfeiting deed, which one of them by using the QR Code in the Deed. Prudence needs to be done by a Notary Public, including keeping the deed of forgery measures. The safeguard measures need to take into account the provisions of legislation, as noted in UUJN Article 38 Paragraph (1) that: "each certificate shall consist of: a. Early Head Deed or Deed, b. Deed Agency, c. Closing the end Deed or Deed. This study aims to: 1 ) identify and analyze about the inclusion of the QR Code on the terms of the Deed Act No. 2 of 2014 on the change of Act No. 30 of 2004 concerning Notary; and 2) determine the position of Deed which included the QR Code on the deed by Act No. 2 of 2014 on the change of Act No. 30 of 2004 concerning Notary.

Keywords: Analysis of Juridical; QR Code; Deed; Notary Law.
\end{abstract}

\section{Introduction}

Progress of century and modern era as current developments in the World Criminal Law is growing, due to the existence of a purpose and desire that is not well done by certain parties. Crime often also occurs in the legal profession, which one of them on notary profession. Notary today often problematic because the deed authentic he made has indications contains elements not criminal, this was due to less precautionary notary to the parties facing in making deed authentic frequently taking opportunities for the sake of advantage themselves by doing crimes, such as giving letter false and false description into created by notary deed.

So we need a safety in the Acts of Notary made, the security of one of them with a QR Code Contains Lists the type Deed, Title Deed, Number Deed, Deed Date, Name Notaries, Notary Public Address and Phone Number.

According to Article 1 Paragraph (1) of Act No. 2 of 2014 on the Amendment of Act No. 30 of 2004 concerning Notary (hereinafter referred UUJN) mentions the Notary Authority, namely: "Notaries are public officials who are authorized to make authentic deed and have other authority referred to in this act or pursuant to other laws."

The necessity of a written deed made before a notary someone is to ensure legal certainty for the parties entered into an agreement and any other desired or the parties, to the extent not bertentangangan with the act, which is poured into the deed.

Deed is proof that the perfect tool, strongest and sold so that in addition to ensure legal certainty, deed also can avoid the occurrence of the dispute. pouring a deed, agreement, in the form of deed decision is considered better than in down letters poured in hand,

\footnotetext{
${ }^{1}$ Master of Notary UNISSULA, Semarang, email: angga1978.ah@gmail.com

2 Lecturer Master of Notary UNISSULA, Semarang

${ }^{3}$ Lecturer Master of Notary UNISSULA, Semarang

${ }^{4}$ Habib Adjie, 2017, Penafsiran Tematik Hukum Notaris Indonesia berdasarkan Undang-Undang Nomor 2 Tahun 2014 tentang perubahan Undang-undang No. 30 Tahun 2004 tentang Jabatan Notaris, Jilid 2, Refika Aditama, Bandung,p.1.
} 
although signed on the stamp, which is also confirmed by the signature of witness. ${ }^{5}$ From the description above, this study aims to conduct analisis juridical Act No. 2 of 2014 on the Amendment Act No. 30 of 2004 On Notary relating toInclusion of QR Code provisions in the Deed, as well as knowing the Status Deed with included the QR Code on the deed, by provisionsAct No. 2 of 2014 on the Amendment Act No. 30 of 2004 On Notary.

\section{Research methods}

The method used is a normative juridical method. Legal research that lays the Law as a System Building Norms. Norm system in question is about principles, norms, rule, of Laws, Covenants and Doctrine (teachings). ${ }^{6}$ And put legislation and appropriate legal norms existing problems. Besides, researchers also conducted interviews method to practitioners who was the initiator of the security Notary Deed, incorporated in Indonesia Notary Community (INC), namely: Dr. Mohammed Hafidh, SH, M.Kn. About how the security deed and whether or not the rules are violated legislation in the inclusion of the QR Code on the deed.

\section{Results and Discussion}

\subsection{Juridical Analysis inclusion of $Q R$ Code provisions in the Deed}

As has been written in the Notary law Article 1 (7), which reads: Deed hereinafter called the deed is a deed authentic made by or in the face notary by form and procedures are in set in this act.

Notary Has Vital Role in Determining an Action can be poured in the Form of Deed or not. Sebelum up In this Decision notary must thinking and view all documents in the show to the notary, covers all showing to him. Listen description evidence or statement parties facing.

The decision must be based on the law reason can explain to the party, and most important decisions taken again later must pay attention to all aspects of legal, including legal problems will arise in the future. In addition every created by notary deed shall has reasons and facts that support for deed, which the relevant or ada legal considerations that must explain to the parties.

Notaries in running tasks his post should remain on the corridor has been defined in the notary law and notary code, but there is still notary who did not run.

Judging from the practice of justice, on essentially a notary in carrying his post seen from dimensions fundamentals, a notary must running his post accordance with the act, the notary code, noting aspects of prudence, accuracy, honesty and trustful if this aspect is overlooked in the creation of deed, then the notary will incurred due to violation of fundamental principles that should be filled.

A deed surely have provisions on format, rules, rules of writing, shape of the notary deed. Rules about this based on article 29 of the stamp duty rule 1921, conditions must filled as follows: ${ }^{7}$

- Sized white paper with a thickness of $1 / 2$ page A3 paper Approximately 80 grams (g)

\footnotetext{
${ }^{5}$ Bakti, Otentitas Suatu Akta Autentik, Diakses dari https://bh4kt1.wordpress.com /2010/12/30/otentisitas-suatu-akta-Autentik, on March 22, 2019

6 Mukti Fajar dan Yulianto Achmad, 2015, Dualisme Penelitian Hukum Normatif \& Empiris, Pustaka Pelajar, Yogyakarta, p. 34

7 Talkonlaw, Format Aturan, Tata Tulis \& Bentuk Akta Notaris, Retrieved from https://talkonlaw.wordpress.com/2016/03/23/format-aturan-tata-tulis-bentuk-akta-notarisdalam-microsoft-word/ , On the date March 26, 2019
} 
- Letter Pica (Typewriter) or Font Courier New (Computers)

- Each page consists of 30 Line (For Typewriter) or up to 30 Line (For Computer) Sentence Down.

- Distance Writing / Punctuation from Left Edge Blank Paper 7cm section to place Renvoi, from Rio de SMA Paper $2 \mathrm{~cm}$ and $3 \mathrm{~cm}$ from the edge of the Lower Paper. Between letters, words Sentences should not be Empty Required with Flat Line Up to the Right Bank section of the paper.

Other matters that should be noted in the making deed need to consider provisions of legislation, which is more defined according to UUJN in article 38 through article 65, in case this writer tried exposing the contents of UUJN related to writing and conditions about preparation of deed, which is compulsory for loaded for as one of terms authenticity deed. Article intended as stated in article 38 of Act No. 2/2014 are: ${ }^{8}$

- Every deed consists of: Early Deed or Deed head; Deed body; and End or cover Deed.

- Beginning of the Deed or Deed head includes:Title deed; Deed number; Hour, day, date, month and year; and Full name and domicile of the notary.

- Body Deed contains: Full name, place and date of birth, nationality, occupation, position, position, place of residence the applicant and / or the people they represent; Information on the positions of acting applicant; ${ }^{9}$ Deed contents which is the will and desire of the parties concerned; and Full name, place and date of birth, and occupation, position, status, and place of residence of each witness identification.

- End or closing Deed contains: a description of the reading of the deed referred to in Article 16 paragraph (1) letter matau Article 16 (7); a description of the signature and the signature or translation deed if there is; full name, place and date of birth, occupation, position, position and place tinggaldari each witness Deed; and no description of the changes occurring in the manufacture of paper or uraiantentang the changes that can be an addition, deletion, or penggantianserta number of amendments.

- Deed in Lieu and Acting Notary, besides including the provisions referred to in paragraph (2), (3) and (4), also contains the number and the date of appointment, as well as the officials who picked it up. "

\subsection{Deed notch by including a $Q R$ code on the deed.}

Notary deed as a deed of authentic has important functions in society. the need for written proof, in the form of authentic deed rise in line with increasing demand for rule of law, which is one principle of the state of law.

Deed is proof that the perfect tool, strongest and sold so that the addition can ensure legal certainty, deed can avoid the occurrence of the dispute. Pouring a deed, agreement, in the form of deed decision considered better compared to put it in the mail in the lower hand signed above although stamp, which is also reinforced by the signature of the witness. It shall be made from the outset intentionally to proof later. The nature of the written agreement in the form of deed that does not make the validity of the Agreement but only to be used as evidence at a later date. ${ }^{10}$

Problems often occur and are often carried out by the notary deed is not read to the

\footnotetext{
${ }^{8}$ Habib Adjie, 2018, Memahaki dan Menguasai Teori Akta Notaris Ragam Awal Akta, Komparisi dan Akhir Akta Notaris, Semarang, Duta Nusindo, p.54

${ }^{9}$ On the Explanation of Law 2/2014, letter b, defined as "Top Acting applicant" is the Basic Law.

${ }^{10}$ Umar Ma'ruf, Tinjauan Hukum Kedudukan dan Fungsi Notaris Sebagai Pejabat Umum Dalam Membuat Akta Autentik, Jurnal UNISSULA, 2016, Vol. III, No. 3 (370-380),p. 372
} 
parties, signed outside the notary office on the grounds that do not fit UUJN and read the deed, but performed by a notary staff. If it happens then the authentic deeds will be degraded to the deed under the hand. So that degradation of the deed of authentic become deed under hand, are actions that do not refer to UUJN.

\section{1) Position deed the deed under degraded into hand}

Described in Article 16 paragraph (1) letter $\mathrm{m}$ UUJN, which reads as follows: "Deed before applicant read in the presence of at least two (2) witnesses, or four (4) witnesses specifically for the manufacture Deed testament under the hand, and signed on the spot by applicant, witnesses and Notary" In Article 16 (7) UUJN reads: "The reading of the Deed referred to in paragraph (1) letter $m$ not mandatory, if applicant requires that the Deed does not read because applicant have read yourself, know, and understand its contents, provided that it is stated in the cover Deed and on every page Minuta Deed initialed by applicant, witnesses and Notary Public. "

UUJN in Article 40, reads: "Every deed which was read by the Notary attended by at least two (2) witnesses, unless the regulations specify otherwise."

And also contained in Article 41 UUJN, reads: Violation of the provisions referred to in Article 38, Article 39 and Article 40 resulted in deed only has the strength of evidence as the deed under the hand. "And in Article 44 Paragraph (1) UUJN, reads: "As soon as the deed was read, the deed was signed by every applicant, witnesses and Notary, unless there applicant unable to sign with tell the reason."

Of the provisions of articles of the UUJN mentioned above can be explained that, everything actions or deeds in making Deed shall be in accordance with UUJN and will not result in the position when Deed becomes degraded into a Deed Under the Hand. And the inclusion of the QR Code as one of the security deed is not an act against UUJN. The position of the deed with the qr code for made in accordance with the deed authentic uujn remains. Because in the QR code contains the text in the form of type deed, title deeds, deed number, date of deeds, notary name, address and telephone numbers notary public notary.

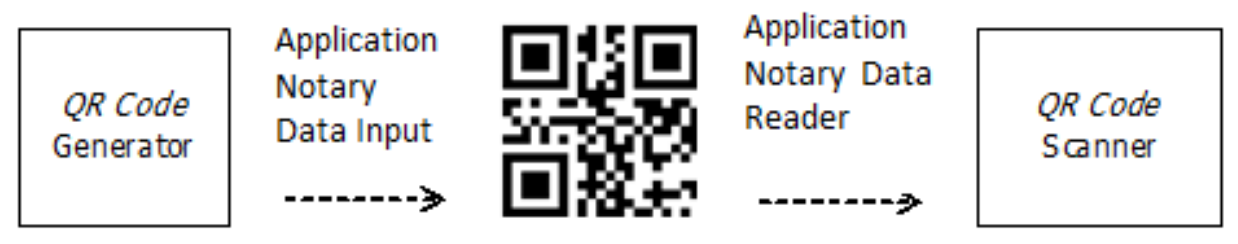

\section{2) Authenticity of a Deed}

A deed admitted to the authenticity certainly based on provisions of legislation. When not in accordance with the provisions of law can be said that the deed notary deed can be regarded as hands down unusual or deed, although notary though. Due to be recognized and accepted as authentic deed shall in accordance with the rules applicable legislation.

Speaking of the deed as authentic evidence can be found in article 1868 of the civil code, namely: ${ }^{11}$ "An authentic deed is a deed made in the form prescribed by the Act by or in the presence of a public official authorized to it in the certificate was made." Also contained within the UUJN Article 1 (7) vaguer about Deed, which reads: "Deed is authentic deed made by or in the presence of a Notary according to the form and manner set forth in this Act."

Notary deed, in that article, interpreted as a deed of authentic made by or in the light of the notary, according to forms and procedures set forth in this act. In grammatical, in the great dictionary of indonesian, deed interpreted as letter exhibit containing statement

${ }^{11}$ The draft Civil Code, Article 1868 
(Description, Recognition, Decision, etc.) about the events judgments made by regulations applicable, witnessed and authorized by the official official, in this case the general authorities are notary Public. So deed must be made by and in the light of the notary is not in the light of staff or employees notary, because if this happens deed that made it degraded into deed under the hand is no longer a deed.

\section{3) Material terms of the deed of authentic}

Deed is a writing according to re van esch, as evidence, material used to explain the article must meet several requirements, among others: ${ }^{12}$

- It would type material used. This relates to the Notaries obligation to make Saving Minuta Deed and Deed so Deed survive when stored;

- Resistance to counterfeiting so that more Memberkan Guarantees for the Parties;

- Orisinilitas that there is only one (1) Minuta Deed of the "Original", except for a Deed In originali made in some fixed Duplicates Considered "Original";

- Publicity for the stakeholders for saw;

- The data contained in the deed could soon discovered or looks easy; and

- Easily moved deed.

Material resilience of deeds in pernyimpanan process needs to be considered by a notary for deed documents are documents state that must be maintained and kept its existence, and often referred to as the protocol notary.

\section{Closing}

\subsection{Conclution}

Based on the research results can be concluded as follows:

- That provision preparation of a deed has been regulated in notary law (UUJN) so that the act which became platform and reference for the a notary in carrying out his post. Has been set in UUJN, structure and content of the deed, contained in article 38 UUJN that the composition of a deed consists of the head / early deed, the agency / contents deeds and end / cover deed. And in general there are also between the home deed by deed contents are comparation and premise. Against other things that aims to provide security to avoid counterfeit deed, such as the inclusion of the QR code on the basis of juridical deed no prohibition would be it. The aim to provide security so that the deed can be done with the good and right not contrary to UUJN.

- That UUJN is the foundation deed of notary in conducting the manufacture of provisions contained in the articles is a basic law that must be obeyed by a notary public. In UUJN Article 16 Paragraph (1) Letter m; Article 16 Paragraph (7); Article 40 Paragraph (1); Article 41 and Article 44 Paragraph (1) provisions requiring a deed to be read and if not done then the deed will be degraded into a deed under the hand. The position of the notary deed the deed attached materials including, where the parties in the deed such has been dies, sheet this amendment is acceptable because the deed of power law fixed. And position deed which embody the QR code on deed for no change, no change, no adding words, which makes the meaning or tafsir others with substance chief deed, content deed and closing deed is legitimate because there is no rule that prohibit in UUJN.

\subsection{Suggestions}

- Should according to the author, in notary law need for additional provisions, either in

12 Notaris arief, Otensitas Suatu Akta Autentik, Retrieved from https://notarisarief.wordpress.com/2011/05/15/authenticity-a-certificate-authenticated/, On 6 April 2019 
the articles or in explanation set of conditions security deed, among notaries one with the notary the other so that there is uniformity same standard form securing deed with QR code refer to the QR code issued by the ministry of justice and human rights in the decree of the establishment of a legal entity.

- The public should be given the understanding and explanation other than the contents of the deed which is obliged to read out, there should be additions explanation whether requested or not by the Client of a Notary, that the Deed that has a notch with a magnitude of Law Still, Being a tool Proof Strong, and also about Security QR Code Form Deed Society should also be given the understanding that the QR code is used as a Security Deed.

\section{Bibliography}

\section{Book}

[1] Habib Adjie, 2017, Penafsiran Tematik Hukum Notaris Indonesia berdasarkan UndangUndang Nomor 2 Tahun 2014 tentang perubahan Undang-undang No. 30 Tahun 2004 tentang Jabatan Notaris, Jilid 2, Refika Aditama, Bandung.

[2] Habib Adjie, 2018, Memahaki dan Menguasai Teori Akta Notaris Ragam Awal Akta, Komparisi dan Akhir Akta Notaris, Duta Nusindo, Semarang.

[3] Mukti Fajar dan Yulianto Achmad, 2015, Dualisme Penelitian Hukum Normatif \& Empiris, Pustaka Pelajar, Yogyakarta.

\section{Internet}

[1] Blog: Bakti, Otentitas Suatu Akta Autentik, Diakses dari https://bh4kt1 .wordpress.com /2010/12/30/otentisitas-suatu-akta-Autentik, accessed on 22 March 2019.

[2] Blog: Talkonlaw, Format Aturan, Tata Tulis \& Bentuk Akta Notaris, Diakses dari https://talkonlaw.wordpress.com/2016/03/23/format-aturan-tata-tulis-bentuk-aktanotaris-dalam-microsoft-word/, accessed on 26 March 2019.

[3] Blog: Bakti, Otentitas Suatu Akta Autentik, Diakses dari https://bh4kt1 .wordpress.com /2010/12/30/otentisitas-suatu-akta-Autentik, accessed on 22 March 2019.

[4] Blog: Notarisarief, Otensitas Suatu Akta Autentik, Diakses dari https://notarisarief.wordpress.com ～/2011/05/15/otentisitas-suatu-akta-otentik/, accessed on 6 April 2019

\section{Constitution}

[1] Act No. 2 of 2014 on the Amendment of Act No. 3 of 2004 on Notary

[2] The Civil Code, Article 1868

\section{Journals}

[1] Umar Ma'ruf, 2016, Tinjauan Hukum Kedudukan dan Fungsi Notaris Sebagai Pejabat Umum Dalam Membuat Akta Autentik, Jurnal UNISSULA, Vol. III, No. 3 